\title{
Use of reduced doses of eCG applied by different routes in the TAI program in Santa Ines sheep
}

\section{Utilização de doses reduzidas de eCG aplicadas por diferentes vias em programa de IATF em ovelhas da raça Santa Inês ${ }^{1}$}

\author{
Karla Dias Antunes-Melo ${ }^{1 *}$; Veronaldo Souza de Oliveira ${ }^{2}$; \\ Anselmo Domingos Ferreira Santos ${ }^{3}$; Claudio Alvarenga de Oliveira ${ }^{4}$; Lícia \\ Mendes Mendonça ${ }^{5}$; Julianne Santiago Silva Goveia ${ }^{6}$; Thiago Santos Almeida ${ }^{7}$
}

\begin{abstract}
The aims of this study were to improve the cost-benefit ratio of the application of artificial insemination in fixed time (TAI) by the transcervical route in sheep, to test the dosage reduction and the use of the vulvar submucosa (VSM) route as an alternative for the application of equine chorionic gonadotropin (eCG) on the efficiency of the synchronization protocol and fertility to artificial insemination (AI) and to measure the level of cortisol in ewes as a result the application of this biotechnique. Blood samples were collected before AI, immediately after AI and seven days after AI. Six groups of twenty animals were used, and each group received doses of 200,300 and $400 \mathrm{IU}$ of eCG by the intramuscular route (IM) and VSM. Estrus was detected, and 48 hours later, the inseminations were performed by the transcervical route. Among the 120 treated ewes, $87.5 \%$ came in estrus. The percentage of the intrauterine deposition of semen was $88.3 \%$. The pregnancy rate ranged from 20 to $70 \%$ between treatments, with an average of $46.66 \%$. The VSM route was viable for the application of eCG in doses of 300 and $400 \mathrm{IU}$. The reduction in the eCG dose to $200 \mathrm{IU}$ by the IM route reduces costs while maintaining the efficiency of estrus synchronization protocols and TAI with frozen semen in Santa Ines ewes. The average levels of cortisol were significant, at $1.15,2.86$ and $0.52 \mu \mathrm{g} / \mathrm{dL}$ according to the three collections, being higher after the animal was off the easel at the end of AI. The procedures for performing the transcervical AI technique indicate that stress in the animals produces satisfactory fertility results and a low cost in multiparous ewes of the Santa Ines breed.
\end{abstract}

Key words: Application route,_artificial insemination, hormones, sheep, stress

\section{Resumo}

Os objetivos deste trabalho foram melhorar a relação custo benefício da aplicação da técnica de inseminação artificial pela via transcervical em tempo fixo (IATF) em ovinos, testando a redução da dose e da utilização da via submucosa vulvar (SMV) como alternativa na aplicação da gonadotrofina

\footnotetext{
1 Médica Veterinária, Discente de Doutorado, Universidade Federal de Minas Gerais, UFMG, Belo Horizonte, MG, Brasil. E-mail: kda_vet@hotmail.com

2 Prof., Pesquisador, Dept ${ }^{\circ}$ de Zootecnia, Universidade Federal de Sergipe, UFS, São Cristóvão, SE, Brasil. E-mail: veronaldo@ ufs.br

3 Prof., Pesquisador, Dept ${ }^{\circ}$ de Medicina Veterinária, UFS, São Cristóvão, SE, Brasil. E-mail: anselmodfsantos@yahoo.com.br

4 Prof., Pesquisador, Dept ${ }^{\mathrm{o}}$ de Reprodução Animal, Faculdade de Medicina Veterinária e Zootecnia, Universidade de São Paulo, USP, São Paulo, SP. Brasil. E-mail: cadolive@usp.br

5 Enga Agra ${ }^{\mathrm{a}}$, M.e em Ciências, UFS, São Cristóvão, SE, Brasil. E-mail: agrolicia@yahoo.com.br

6 Eng ${ }^{\mathrm{a}}$ Agr ${ }^{\mathrm{a}}$, M.e em Zootecnia, UFS, São Cristóvão, SE, Brasil. E-mail: julygoveia@gmail.com

7 Zootecnista, M.e em Zootecnia, UFS, São Cristóvão, SE, Brasil. E-mail: tsa_almeida@yahoo.com.br

* Author for correspondence
} 
coriônica equina (eCG) sobre a eficiência do protocolo de sincronização e fertilidade à inseminação artificial (IA), e mensurar o nível de cortisol nas ovelhas em conseqüência da aplicação desta biotécnica. As coletas de sangue foram realizadas antes da IA, após a IA e sete dias após IA. Foram utilizados seis grupos de vinte animais, onde cada grupo recebeu dosagens de 200, 300 e 400 UI de eCG pela via intramuscular (IM) e SMV. O estro foi detectado e 48 horas após feitas as inseminações pela via transcervical. Das 120 ovelhas tratadas, 87,5\% manifestaram estro. O percentual de deposição intrauterina de sêmen foi de $88,3 \%$. A taxa de gestação variou de 20 a $70 \%$ entre os tratamentos, obtendo-se média de 46,66\%. A via SMV foi viável para aplicação de eCG em doses de 300 e 400 UI. A dose de eCG para 200 UI pela via IM apresentou melhor custo/benefício mantendo a eficiência dos protocolos de sincronização de estro e IATF com sêmen congelado em ovelhas da raça Santa Inês. Os níveis médios de cortisol foram significativos com 1,15;2,86 e $0,52 \mu \mathrm{g} / \mathrm{dL}$ de acordo com os três momentos de coleta, sendo maior após a IA. Apesar dos procedimentos para realização da técnica de IA transcervical indicar estresse nos animais, apresenta resultados satisfatórios de fertilidade e baixo custo em ovelhas multíparas da raça Santa Inês.

Palavras-chave: Estresse, hormônios, inseminação artificial, ovino, via de aplicação

\section{Introduction}

Artificial insemination (AI) in sheep has existed for years in Brazil, but its use by farmers is still low in herds, especially related to transcervical $\mathrm{AI}$ at a fixed time with frozen semen. In addition, the anatomic difficulty of the sheep cervix in passing the insemination pipette, the high costs of the hormones that are used in induction protocols and synchronization estrus and ovulation are other limiting factors in this procedure. Transcervical artificial insemination has the potential for widespread use. Therefore, before using this biotechnique, it is of fundamental importance to study its effects on the reproductive physiology of the ewes.

The difficulty of passing the insemination pipette through the cervix has been practically overcome by the use of the traction technique and its manifestation, with reports of intrauterine insemination depositing semen on the order of $84 \%$ in multiparous ewes (OLIVEIRA et al., 2010). The costs of hormones to induce estrus and ovulation synchronization of one ewe are approximately 20-30 reais, depending on the protocol and doses. The protocols that are recommended by the manufacturers of hormones to synchronize estrus using doses that are often high based on large wool ewe breeds are unnecessary at times, especially if we consider the particularities of our native breeds, such as the Santa Ines.
The vulvar submucosa (VSM) route of application is not very suitable routinely in estrus synchronization protocols; however, Gioso et al. (2005) reported satisfactory results in terms of estrus expression responses using this route with reduced doses of cloprostenol (prostaglandin analogue) in cattle because, according to these authors, these doses make faster the action of hormones in the ovary region. Chacur et al. (2010) reported that treatments with low doses of cloprostenol intramuscular (IM) or VSM may be used in estrus induction with similar pregnancy rates in in cyclic Nellore cows with a good body condition. It is possible that using this route with gonadotropins may reduce the cost of the hormones in induction protocols and in synchronizing estrus and ovulation in ewes and may promote an increase the use of artificial insemination in fixed time (TAI) transcervically in sheep, thereby optimizing the reproductive potential and increasing the genetic gain in herds.

Some authors have questioned the fact that the cervical AI technique causes stress in animals compared to the laparoscopic technique, leading to increased levels of cortisol and consequently interference with the ovulation rates, causing low fertility in induction protocols and in synchronizing estrus and ovulation (HOUDEAU et al., 2002; BREEN et al., 2005). 
According to Breen et al. (2005), elevated plasma levels of cortisol in ewes interfere with the follicular phase by suppressing LH pulses, resulting in the release of estradiol and follicle-stimulating hormone (FSH).

The cortisol concentration is an important stress level indicator in the individual. Animals in stress seek behavioral and physiological adjustments as necessary to conform to adverse environmental conditions, minimizing the effects of stress and restoring balance (CHABEL et al., 2009).

The objectives of this work were to test the effect of dose reduction and the use of the vulvar submucosa (VSM) route in the application of equine chorionic gonadotropin (eCG) on the efficiency of the synchronization protocol, fertility to artificial insemination, and prolificacy and to measure the level of cortisol in ewes in response to the application of this biotechnique.

\section{Material and Methods}

The experiment was conducted between the months of June 2011 and January 2012 on two farms breeding Santa Ines ewes in the municipality of Graccho Cardoso and Maruim. The Agriculture New Northeast farm (property "A") is located in the municipality of Gracho Cardoso, Hinterland of the State of Sergipe, $77.2 \mathrm{~km}$ from the capital Aracaju, at latitude $10^{\circ} 13^{\prime} 36^{\prime \prime}$ south and longitude $37^{\circ} 11$ '54" west, at an altitude of 242 meters and with $700-900 \mathrm{~mm} /$ year of rainfall. Property B was located in the municipality of Maruim (Flock AFN) at latitude $10^{\circ} 44^{\prime} 15^{\prime \prime}$ south and longitude $37^{\circ} 04^{\prime} 54^{\prime \prime}$ west, at an altitude of 10 meters in the East Region of Sergipe, $30.0 \mathrm{~km}$ from Aracaju and with 500-700 $\mathrm{mm} /$ year of rainfall (GEOGRAFIA DE SERGIPE, 2010).

A total of 120 multiparous Santa Ines ewes were selected, including 60 ewes in each property with an average age of three years, a body weight between 35 and $40 \mathrm{~kg}$ and a body condition score (BCS) from
3.0 to 3.5 (range of scores from 0 to 5) (RUSSEL; DONEY; GUNN, 1969). The animals were properly identified with numbered earrings or collars for ease of handling and control. In the two properties, the system of semi-intensive farming dominated, and the animals had access to specific mineral salt for sheep and water ad libitum.

The estrus females of both properties were synchronized using a protocol lasting nine (9) days, by applying intravaginal sponges that were impregnated with $60 \mathrm{mg}$ of medroxyprogesterone acetate (MPA). These sponges were inserted at 08:00 am on day 0 (zero), and on the 7th day at 08:00 am, $100 \mu \mathrm{g}(0.5 \mathrm{~mL})$ of prostaglandin (PGF2a, ScheringPlough, Rio de Janeiro, RJ, Brazil) was administered intramuscularly (IM). On the 9th day at the time of sponge removal, the 60 ewes in each property were randomly divided into three groups of 20 animals each to receive 08:00 am dosages of 200, 300 and $400 \mathrm{IU}$ of equine chorionic gonadotropin (eCG), wherein each group of 20 animals experienced a varied route of administration, including 10 intramuscular and $10 \mathrm{VSM}$ routes. Estrus detection was performed on the 10th day of the protocol every 8 hours with the aid of ruffians. On the 11th day at 08:00 am, the females were inseminated from the same inseminator between 48 and 56 hours after the removal of the vaginal sponges. At the time of AI, the females were positioned and immobilized in the supine position by raising their hind limbs on an easel that was $90.0 \mathrm{~cm}$ high. To visualize the cervix, a vaginal speculum was used, and along with a flashlight and Allis clamps, the entry of the cervix was determined, followed by the removal of the vaginal speculum and pulling up the forceps to open to the vulva. The traction and attachment of the cervix were manipulated by an applicator expander (Model High Genetics) through the cervical rings until the cervix was reached and was held by transcervical AI in an attempt to deposit the sperm in utero.

All of the ewes, whether in estrus or not, were inseminated with frozen semen in straws of 0.25 
$\mathrm{mL}$ from the player breed Santa Ines, acquired from the central semen accredited in Brazil. The diagnosis of pregnancy was performed using an ultrasound device between 35 and 40 days after insemination. The following parameters were evaluated: interval between sponge removal and the beginning of estrus (ISRBE); animals in estrus (AE) corresponding to the number of ewes in estrus by the total treated ewes; time spent in AI (TAI), which is the time between the clamping edge of the cervix, its traction and the insemination itself; deposition site of the semen (superficial cervical, middle, deep or intrauterine); pregnancy rate; prolificacy; and hormonal costs according to each treatment.

Statistical analyses of the data of the properties were grouped by the absence of significant differences $(\mathrm{P}<0.05)$ between them; therefore, the experiment was conducted in a completely randomized design in a $3 \times 2$ factorial arrangement with three eCG doses (200, 300 and 400 IU ) and two routes of administration (IM and VSM). Parametric ISRBE (hours) and TAI (minutes) data were analyzed by the GLM procedure in the SAS statistical package (2009). The nonparametric data as a percentage of animals in estrus, pregnancy rate (number of ewes calved by the number of exposed ewes) and prolificacy (number of offspring by the number of calving ewes) were compared using the chi-square test. The results were subjected to an analysis of variance, and differences were evaluated by Student-Newman-Keuls (SNK) test using the ANOVA procedure of SISVAR 5.0 (FERREIRA, 2007). The tests were analyzed using a significance level $\mathrm{P}<0.05$.

The analysis of the induction protocols costs and synchronization of estrus and ovulation for each treated ewe, considering only the employed hormones, was based on the price of the domestic market in May 2011 for the $60 \mathrm{mg}$ MAP as calculated in sponge units as the basis of a cloprostenol dose of $0.5 \mathrm{~mL}$ of eCG and doses of 200, 300 and 400 IU. The value that was produced by each treatment lamb is equal to the number of treated females multiplied by the cost of the hormonal treatment per ewe divided by the number of litters.

For the cortisol analysis, blood samples were collected $(10 \mathrm{~mL})$ by jugular venipuncture in heparinized vacutainer tubes before AI (immediately before going on the easel), immediately after AI (immediately after getting off the bridge) and seven days after AI (the rest of the animals). The samples were centrifuged at $3000 \mathrm{rpm}$ for 15 minutes, and the plasma was analyzed by a semi-quantitative test radioimmunoassay (RIA) kit using CORTISOL COAT-A-COAT (Siemens) performed in laboratory hormonal measurements (LDH) of the Faculty of Veterinary Medicine and Animal Husbandry (FMVZ), University of São Paulo (USP).

A statistical analysis of the different cortisol levels was performed by the SNK test using the ANOVA procedure of SISVAR 5.0 (FERREIRA, 2007) with a significance level of $\mathrm{P}<0.05$.

\section{Results and Discussion}

Of the 120 treated ewes, $87.5 \%$ expressed estrus, with no significant difference $(\mathrm{P}>0.05)$ between treatments (Table 1), indicating that regardless of the eCG dose (200, 300 and 400 IU) or the application (IM and VSM) that was used for estrus synchronization, the protocol was efficient. A higher percentage was observed by Oliveira et al. (2010), who obtained 93.12\% using the same protocol. The different routes of administration of eCG also showed no significant difference $(P>0.05)$ in the estrus detection time. The ISRBE (hours) was 42.28 \pm 8.33 , with no significant difference $(\mathrm{P}>0.05)$ between treatments, although there was a higher concentration of ewes in estrus between 41 and 48 hours $(50.6 \%)$. The mean time to perform the AI was $4.9 \pm 2 \mathrm{~min}$, and there were no differences $(\mathrm{P}>$ 0.05 ) between the treatments (Table 1), confirming the results of Oliveira et al. (2010), who obtained an average time of less than $5 \mathrm{~min}$ in $65 \%$ of the animals $(n=110)$. The highest pregnancy rate that was observed in this study was also associated with 
less time spent in the AI, concentrated in intervals from $2-3 \min (55.32 \%)$ and $4-5 \min (57.14 \%)$, whereas intervals of greater than 5 min $(19.35 \%)$ showed a decrease in the pregnancy rate. Using the same procedure, Taqueda et al. (2011) also observed higher pregnancy rates when inseminations were performed from 2-3 $\mathrm{min}(45.8 \%)$ and $4-5 \mathrm{~min}$
$(30.8 \%)$, with low rates at intervals of greater than $5 \mathrm{~min}$. Most of the animals increased from $5 \mathrm{~min}$ to the manipulation of AI, with the inseminating pipette not passing through all of the cervical rings, limiting the deposition of semen in the superficial or middle region of the cervix and contributing negatively to the pregnancy rates.

Table 1. Animals in estrus (AE), interval between sponge removal and the beginning of estrus (ISRBE in hours $\pm \mathrm{SD}$ ), time spent with AI (TAI in minutes $\pm \mathrm{SD}$ ) subjected to estrus synchronization protocol in Santa Ines ewes.

\begin{tabular}{lccccccc}
\hline Parameters & $\begin{array}{c}\text { T1 } \\
\text { 200 IU/IM }\end{array}$ & $\begin{array}{c}\text { 200 IU/ } \\
\text { VSM }\end{array}$ & $\begin{array}{c}\text { T00 IU/IM } \\
\text { IN }\end{array}$ & $\begin{array}{c}\mathbf{3 0 0} \text { IU/ } \\
\text { VSM }\end{array}$ & $\begin{array}{c}\text { T5 } \\
\mathbf{4 0 0} \text { IU/IM }\end{array}$ & $\begin{array}{c}\text { 400 IU/ } \\
\text { VSM }\end{array}$ & Mean \\
\hline AE (\%) & $85 \%(17 / 20)$ & $85 \%(17 / 20)$ & $90 \%(18 / 20)$ & $90 \%(18 / 20)$ & $90 \%(18 / 20)$ & $85 \%(17 / 20)$ & $87.5 \%$ \\
ISRBE (h) & $43.36 \pm 8.05$ & $45.05 \pm 8.53$ & $42.03 \pm 8.09$ & $41.24 \pm 8.86$ & $39.34 \pm 8.17$ & $42.63 \pm 8.27$ & $42.28 \pm 8.33$ \\
TAI (min.) & $4 \pm 2$ & $6 \pm 4$ & $5 \pm 2$ & $4 \pm 2$ & $6 \pm 3$ & $5 \pm 3$ & $4.9 \pm 2$ \\
\hline
\end{tabular}

$\mathrm{SD}=$ standard deviation

Source: Elaboration of the authors.

It is possible that with the increasing time of manipulation of the cervix, passage of the pipette has occurred, releasing hormones or uterine modifications that reduce fertility rates, because, according to Houdeau et al. (2002), the delay in the handling time of AI by cervical occurs via the increased release of oxytocin and an increase in the uterine activity, contributing to the reduction in the fertility rate of the analyzed animals.

Although the deposition of semen into the uterus region occurred at a high percentage $(88.3 \%)$, the animals did not reflect the same percentage in terms of pregnancy, as the pregnancy rates ranged from 20 to $70 \%$ (Table 2), confirming the reports of Houdeau et al. (2002) that the manipulation of the reproductive tract of these animals may release hormones or change the uterine activity when using transcervical AI. The average pregnancy rate in this study was $46.66 \%$; if one considers the method of insemination and the use of frozen semen, it appears that this rate is as good as expected with the sheep. Oliveira et al. (2010) had a lower mean percentage $(36.6 \%)$ of pregnancy with $84 \%$ frozen semen deposited in utero in Santa Ines ewes using doses of $500 \mathrm{IU} / \mathrm{IM}$ of eCG. There was no significant difference in the pregnancy rates between treatments at 200, $300 \mathrm{IU} / \mathrm{IM}$ and $300 \mathrm{IU} / \mathrm{VSM}$ of eCG (P>0.05), highlighting the lowest dose $200 \mathrm{IU}$ route IM with the highest rate $(70 \%)$, unlike other treatments (Table 2). The pregnancy rate showed differences between treatments, as influenced by the application methods and not by the eCG dose. The average prolificacy rate was $1.36 \pm 0.41$ per calved ewe between treatments, with no significant difference between the treatments, indicating in this experiment that higher doses of gonadotropins, such as 300 and 400, hardly influenced the pregnancy rate or the number of lambs that were born and only contributing negatively to increase the protocol costs. Moreover, Mexia et al. (2004) working with animals of the same breed with natural service and without the application of hormones found similar prolificacy rate values of 1.26. Cardoso et al. (2009) observed a lower prolificacy rate (1.10) with the treatment of $260 \mathrm{IU} / \mathrm{IM}$ of eCG with animals of the same breed. These changes in the pregnancy and prolificacy rates within the breed Santa Ines may be related to the local nutritional management of each property, body score and period of the year. 
Table 2. Pregnancy and prolificacy rates in Santa Ines ewes after hormone treatment with different doses of eCG and routes of administration.

\begin{tabular}{lccccccc}
\hline Parameters & $\begin{array}{c}\text { T1 } \\
\text { 200 IU/IM }\end{array}$ & $\begin{array}{c}\text { T2 } \\
\text { 200 IU/ } \\
\text { VSM }\end{array}$ & $\begin{array}{c}\text { T3 } \\
\text { 300 IU/IM }\end{array}$ & $\begin{array}{c}\text { 300 IU/ } \\
\text { VSM }\end{array}$ & $\begin{array}{c}\text { T5 } \\
\text { 400 IU/IM }\end{array}$ & $\begin{array}{c}\text { T00 IU/ } \\
\text { VSM }\end{array}$ & Total \\
\hline $\begin{array}{l}\text { Pregnancy } \\
\text { rate }\end{array}$ & $\begin{array}{l}70 \% \\
(14 / 20)^{\mathrm{a}}\end{array}$ & $\begin{array}{c}20 \% \\
(4 / 20)^{\mathrm{b}}\end{array}$ & $55 \%(11 / 20)^{\mathrm{a}}$ & $50 \%(10 / 20)^{\mathrm{a}}$ & $\begin{array}{c}45 \% \\
(9 / 20)^{\mathrm{ab}}\end{array}$ & $\begin{array}{c}40 \% \\
(8 / 20)^{\mathrm{ab}}\end{array}$ & $46.66 \%$ \\
Prolificacy $^{*}$ & $\begin{array}{c}1.43 \pm 0.51 \\
(20 / 14)\end{array}$ & $\begin{array}{c}1.25 \pm 0.50 \\
(5 / 4)\end{array}$ & $\begin{array}{c}1.27 \pm 0.47 \\
(14 / 11)\end{array}$ & $\begin{array}{c}1.40 \pm 0.52 \\
(14 / 10)\end{array}$ & $\begin{array}{c}1.44 \pm 0.53 \\
(13 / 9)\end{array}$ & $\begin{array}{c}1.38 \pm 0.52 \\
(11 / 8)\end{array}$ & $1.36 \pm 0.41$ \\
\hline
\end{tabular}

*There was no significant difference $(\mathrm{P}>0.05)$.

Source: Elaboration of the authors.

Certain cortisol levels showed significant differences $(\mathrm{P}<0.05)$ the following average values as collected in the three moments before $\mathrm{AI}$, immediately after AI and seven days after AI: 1.15; 2.86 and $0.52 \mu \mathrm{g} / \mathrm{dL}$, respectively. Higher cortisol levels was recorded immediately after the restraint, $\mathrm{AI}$ and lowering of the bridge of animals during the process of artificial insemination, suggesting that the set of placement procedures, immobilization and insemination may have significantly increased these levels based on reports by Khalid, Haresign e Bradley (1998), who investigated the cortisol response in ewes who underwent cervical insemination or laparoscopic and handling procedures associated with such techniques. These authors observed an increase in the cortisol concentration in the moments in which the animals were contained for cervical insemination and placed on the stretcher for laparoscopic insemination. The peak in the cortisol concentration was similar for both treatments, and it was suggested by researchers that, independent of the insemination method, stress is based on the levels of cortisol.

Regardless of the time taken to pass the insemination pipette through the cervix of animals at the time of AI, there was no significant difference between the determined cortisol levels. The results of the research of Houdeau et al. (2002) showed that regardless of the degree of difficulty of the passage of an insemination pipette through the cervix of an animal, the cortisol level increases just by manipulating the animal.
Even with the increased cortisol levels with the procedures for AI through the cervical route, from the 60 animals that were inseminated in an average of 4 min, we obtained a $53.33 \%(n=32)$ pregnancy rate, which is considered excellent considering the use of frozen semen and insemination by the aforementioned route. Reports of pregnancy rates close to $50 \%$ with frozen semen in AI with ewes mostly involve the technique of laparoscopy. Cortisol levels during the phase after AI ranged between 2.4 and $3.9 \mu \mathrm{g} / \mathrm{dL}$, indicating the state of stress in the animals regardless of the time spent in AI. It is likely that the difficulty in obtaining better pregnancy rates with $\mathrm{AI}$ in ewes may be related to increased circulating cortisol; however, other factors, such as the release of other hormones and changes in the contractility of the uterine lining, may negatively influence these rates, requiring new research with such procedures, route of AI, dosage of other hormones related to reproduction and monitoring of the uterine mucosa response after handling and after insemination.

The protocol costs with synchronizing estrus and ovulation induction were R\$ 4.03 for $60 \mathrm{mg}$ of MAP; R\$ 1.71 for $0.5 \mathrm{~mL}$ of cloprostenol; and R\$ 6.36; 9.54 and 12.72 for doses of 200, 300 and $400 \mathrm{IU}$ of eCG, respectively. The cost per treated ewe was R\$ 12.10 for T1 and T2 (200 IU of eCG); $\mathrm{R} \$ 15.28$ for T3 and T4 (300 IU of eCG); and R\$ 18.46 for T5 and T6 (400 IU of eCG). The value of the lamb that was produced in each treatment varied between 12.10 and 48.40 reais ( $\mathrm{T} 1$ and $\mathrm{T} 2)$. The 
cost of lamb production in $\mathrm{T} 1$ was $\mathrm{R} \$ 12.10$; $\mathrm{T} 2 \mathrm{R} \$$ 48.40; T3 and T4 R\$ 21.83; T5 R\$ 28.40 and T6 R\$ 33.56 .

The value of the hormonal treatment with a dose of $200 \mathrm{IU}$ in the eCG route IM was R $\$ 12.10$, with higher pregnancy and prolificacy rates $(70 \%$ and 1.43), respectively, and a better cost/benefit ratio, approaching the value that was obtained by Cardoso et al. (2009), which was R\$ 10.33 using the MAP protocol with $60 \mathrm{mg}$ impregnated in the sponge, combined with a dose of $260 \mathrm{IU}$ of eCG without the administration of a luteolytic agent, thereby reducing the cost of the protocol. The total value of the lamb varied with the type of treatment, while the highest price that was achieved was $\mathrm{R} \$$ 48.40 with the use of $200 \mathrm{IU} / \mathrm{VSM}$ of eCG, being four times that using $200 \mathrm{IU} / \mathrm{IM}$ of eCG, which was $\mathrm{R} \$ 12.10$. In the case of $\mathrm{T} 1$, which was the lowestcost hormonal protocol, we obtained the highest prolificacy rate $(1.43 \pm 0.51)$ contributing to the reduction in the value of these animals, which was $\mathrm{R} \$ 12.10$.

\section{Conclusions}

The 200-IU dose of eCG via the IM route showed a better cost-benefit in maintaining the efficiency of estrus synchronization protocols and artificial insemination in fixed time with frozen semen in ewes of the breed Santa Ines.

\section{Acknowledgments}

The author expresses his gratitude to CAPES for granting a master's scholarship, Banco do Nordeste of Brazil for financial support, the properties for the use of animals and Dr. Claudio Alvarenga de Oliveira by hormonal analysis.

This article was approved by the bioethics committee and was performed in accordance with the technical standards of biosecurity and ethics.

\section{References}

BREEN, K. M.; BILLINGS, H. J.; WAGENMAKER, E. R.; WESSINGER, E. W.; KARSCH, F. J. Endocrine basis for disruptive effect of cortisol on preovulatory events. Endocrinology, v. 146, n. 4, p. 2107-2115, 2005.

CARDOSO, E.; CRUZ, J. F.; FERRAZ, R. C. N.; TEIXEIRA NETO, M. R.; SANTOS, R. S. Avaliação econômica de diferentes técnicas de inseminação artificial em ovinos da raça Santa Inês. Revista Brasileira de Ciências Agrárias, Recife, v. 4, n. 2, p. 217-222, 2009.

CHABEL, J. C.; VAN ONSELEN, V. J.; MORAIS, M. G.; CORTADA NETO, I. M.; TEDESCHI, B. P. Efeito de um complexo homeopático "Homeobase Convert $H \bowtie$ " em ovinos sob condições de restrição alimentar. Brazilian Journal of Veterinary Research and Animal Science, São Paulo, v. 46, n. 5, p. 412-423, 2009.

CHACUR, M. G. M.; AURÉLIO, P. T. F.; SCALON JÚNIOR, O.; INAGUE, L.; SCALON, L. F.; KRONCA, S. N. Efeitos de baixas doses de cloprostenol via intramuscular ou submucosavulvar na indução do estro e taxas de prenhez em vacas Nelore. Semina: Ciências Agrárias, Londrina, v. 31, n. 2, p. 451-458, 2010.

FERREIRA, D. F. SISVAR versão 5. 0. Departamento de Ciências Exatas. Lavras: UFLA, 2007.

GEOGRAFIA DE SERGIPE. Formação territorial e organização político- espacial. 2010. Disponível em: $<$ http://www.josevalter.com.br/estudante/geografia. htm>. Acesso em: 28 out. 2010.

GIOSO, M. M.; COSTA, E. P.; FERNANDES, C. A. C.; TORRES, C. A. A.; CARVAlHO, G. R. Perfil de progesterona e intervalo ao estro de receptoras bovinas sincronizadas com doses reduzidas de cloprostenol. Revista Brasileira de Zootecnia, Viçosa, MG, v. 34, n. 4, p. 1181-1187, 2005.

HOUDEAU, E.; RAYNAL, P.; MARNET, P. G.; GERMAIN, G.; MORMEDE, P.; ROSSANO, B.; MONNERIE, R.; PRUD'HOMME, M. J. Plasma levels of cortisol and oxytocin, and uterine activity after cervical artificial insemination in the ewe. Reproduction Nutrition Development, v. 42, n. 4, p. 381-392, 2002.

KHALID, M.; HARESIGN, W.; BRADLEY, D. G. Heart-rate responses and plasma cortisol concentrations in ewes: comparison between cervical and laparoscopic intrauterine insemination and their associated handling procedures. Animal Science, Liverpool, v. 66, n. 2, p. 383-387, 1998. 
MEXIA, A. A.; MACEDO, F. A. F.; ALCALDE, C. R.; SAKAGUTI, E. S.; MARTINS, E. N.; ZUNDT, M.; YAMAMOTO, S. M.; MACEDO, R. M. G. Desempenhos reprodutivo e produtivo de ovelhas Santa Inês suplementadas em diferentes fases da gestação. Revista Brasileira de Zootecnia, Viçosa, MG, v. 33, n. 3, p. 658-667, 2004.

OLIVEIRA, V. S.; MATOS, J. E.; FERREIRA, A. D.; AZEVEDO, H. C.; ALMEIDA, T. S. Utilização da técnica da inseminação artificial com sêmen congelado por via transcervical em tempo fixo em ovelhas da raça Santa Inês no Estado de Sergipe. In: REUNIÃO ANUAL DA SOCIEDADE BRASILEIRA DE ZOOTECNIA, 47. 2010, Salvador. Anais... Salvador: UFBA, 2010. p. 1-3.
RUSSEL, A. J. F.; DONEY, J. M.; GUNN, R. G. Subjective assessment of body fat in sheep. The Journal of Agricultural Science, Cambridge, v. 72, n. 3, p. 451454, 1969.

STATISTICAL ANALYSIS SYSTEM - SAS. User's guide. Version 9. 2 ed. Cary: SAS Institute, 2009.

TAQUEDA, G. S.; AZEVEDO, H. C.; SANTOS, E. M.; MATOS, J. E.; BITTENCOURT, R. F.; BICUDO, S. D. Influência de aspectos técnicos e anatômicos nos índices de fertilidade baseado no desempenho da inseminação artificial transcervical em ovinos. ARS Veterinaria, Jaboticabal, v. 27, n. 2, p. 127-133, 2011. 